\title{
MUSICALLY PEDAGOGICAL ASPECT OF WIND SOLO COMPOSITIONS (ON EXAMPLE OF E. V. DENISOV'S CREATIVENESS)
}

\author{
Nemkovich O. M., Hromchenko V. V.
}

\section{INTRODUCTION}

The multifaceted specialized work with artistically instrumental composition occupies the foremost, centrally vocational place into the traditionally academic musical pedagogy. Accentuate, that imaginative content of professional musical masterpiece, as a rule, assumes the applying of wide pallet concerning artistically expressive means, original incarnation of musician's performing possibilities (fingering, timbre-coloristic gradation of instrumental sounding and constructional features of certain musical instrument), as well as particularity of individual artistic reading for one or another musically artistic composition by academic performer-soloist and etcetera.

The above-mentioned thinks are approving of artistic musical composition as a peculiar highly-affective center, the quintessence of professional academic musically pedagogical process.

Contemporary wind academic musically-performing art, in the context of modern musical pedagogy, is represented by artistically perfective masterpieces, which had written by composers for only one stage performer, underline, for single-creator soloist on the concert professional stage. It is this circumstance reflects of the present-day level regarding development of wind solo. This phenomenon, as a bright and formed appearance of contemporary academic musical culture in the $20^{\text {th }}$ - the beginning of the $21^{\text {st }}$ centuries, is presented not only at the modern-day repertoire lists of many educational programs in reference to learning, training-instructional subject "Special instrument (wood and brass wind instruments)", but in the register, particularized catalogue of the famous concert wind compositions, which are most often applying within the framework of different festivals, competitions, culturally educational actions, which are carried out on the stage of divers musically instructional academic institutions.

This contemporary, innovative musically pedagogical new repertoire for those or other professional wind academic instruments solo does not assume the availability of pianist-accompanist into the process of work on the wind solo compositions, because, underscore, they were primarily written by modern composers for only one instrument.

The impetuous magnification of quantity concerning these stage-individual masterpieces for professional wind academic instruments takes the beginning 
in the European musical culture from the second half of the $20^{\text {th }}$ century. This musically creative situation is noted by actively progressive dynamic also at our time. It is this tendency in the contemporary musical practice have generated the above-indicated particularity in relation to having the lessons with students on the all phases of work for musical composition solo namely having classes without participation, involvement occupational pianistaccompanist.

Accentuate, that changeability into the content of the phenomenon "wind solo" was conditioned by increasing the interest to this appearance from the side of many scientists - investigators of musical culture, explorers of professional performing process as well as composers, performers, musical editors and etcetera; what have reflected into contemporary views, inferences, conclusions of many present-day musicians-pedagogues.

The attempt of analysis for wind solo compositions by E. Denisov is produced by authors into represented investigative work from point of view concerning the musically-pedagogical peculiarity of E. Denisov's wind masterpieces solo. The exploration is also carried out by scientist in context actualized at our time the distance form pedagogical communication between professor and student namely young performer wind academic instrument.

\section{Wind solo compositions by E. Denisov in the aspect of wind academic musically-pedagogical practice}

The world famous composer, outstanding musicologist, celebrated pedagogue as well as active public personality Edison Vasilievich Denisov (1929-1996) is specifically distinguished among many composers of the $20^{\text {th }}$ century, which creativeness are noted by particularized attention to the stage-individual wind professional performing namely wind solo.

E. Denisov is unsurpassed musical master in reference to the coverage of wind academic instrumentation and genre pallet of wind solo artistic compositions, concerning understanding of peculiarity regarding this sphere of professional musical creativeness.

The artistically perfect compositions for wind academic instruments solo were written by outstanding musician in the period of 1971-1983, where E. Denisov had accumulated the certain composer experience (Sonata for violin and piano, 1963; Cantata "The Incas' Sun", 1964; Sonata for saxophone and piano, 1970 and others musical compositions), finished and noted by successes of learning at the Tomsk State University as well as Moscow State Conservatory after name P.I. Tchaikovsky, successfully carried out the many musically-folklore specialized expeditions to the Altay, Tomsk and Kursk regions, realized a lot of others musically-creative, artistic events.

E. Denisov's creative heritage for wind professional instruments solo consists of Solo for flute (1971), Solo for oboe (1971), Sonata for clarinet 
solo (1972), Solo for trumpet (1972), Sonata for bassoon solo (1982), Sonata for flute solo (1982), two pieces "Pastoral" and "Movement" for flute solo (1983), five etudes for bassoon solo (1983).

Musically-pedagogical particularity, evaluative educational significance of wind solo compositions by E. Denisov, unfortunately, haven't got the scientific understanding from a lot of teachers and investigators despite of the high level of requirement for noted wind compositions at the vocational working of musicians-pedagogues (learning-methodic, concert-performing, culturally-educational). It is this is one of the profound problems concerning contemporary academy musically-pedagogical think, awareness, underscore, dedicated to the present-day professional wind music.

The topicality of represented investigation is connected by authors' this article also with absolute instrumental and genre multiplicity of compositions for wind instruments solo by E. Denisov. These masterpieces were not done analyzed by scientists into the many explorative works. The modern-day famous Russian clarinetist, pedagogue, composer I. Olenchik (b. 1952) is the author of many compositions for clarinet solo (The cycle 20 caprices for clarinet solo, concert etudes for clarinet solo and others masterpieces solo). Herewith, celebrated master concentrates the creative attention only to the one wind instrument namely clarinet. Renowned composer, trumpeter, conductor, teacher from Great Britain M. Arnold (1921-2006) focuses the particularized artistic looking to the academic genre of fantasy for different wind professional instruments solo (Concert fantasy for tube solo, Fantasy for horn solo, Fantasy for bassoon solo and others wind academic instruments).

The necessity for learning of submitted investigative subject is disclosed by authors of this scientific material also from the historical point of view. There are 12 Fantasies for flute solo by G. Telemann (1681-1767), the multiplicity caprices for flute solo by A. Furstenau (1792-1852), wide popular caprices for clarinet solo by E. Cavallini (1807-1874), 20 etudes-preludes for flute solo by N. Platonov (1894-1967) and others artistically bright compositions at the contemporary musically-pedagogical practice.

The specialized literature, dedicated to the analysis of wind compositions solo by E. Denisov, is expressively characterized by precise problematic and thematic versatility. Masterpieces of wind solo by soviet "avant-gardist", "Mozart of the $20^{\text {th }}$ century" (it is that many foreign musicians called by E. Denisov) is detail investigated by V. Apatsky in the historical aspect ${ }^{1}$. Technologically-performing particularities of the noted compositions, in particular, maximally detail opening of peculiarity concerning instrumental technique, are considered by Z. Burkatsky ${ }^{2}$, I. Viskova ${ }^{3}$, M. Krupey ${ }^{4}$. Genre

\footnotetext{
${ }^{1}$ Апатский В. История духового музыкально-исполнительского искусства. Киев : Задруга, 2012. 408 c.

Буркацький 3. Особистісно орієнтований підхід до віртуозності кларнетиста. Одеса : Друкарський дім, 2010. 166 с.
} 
and artistically-aesthetic diversity of E. Denisov's creativeness, into the context of postmodern culturally-historical period, is studied by A. Danilova ${ }^{5}$, V. Gromchenko ${ }^{6}$ and many others investigators.

We obligatorily have to note the fundamental monograph investigation "Edison Denisov's confession" by D. Shulgin, into the light of submitted the scientific subject. Personality, individuality of this celebrated Slavic composer is opened by author of that famous exploration into the biographic, musically creative as well as worldview and philosophic aspects.

The collective monograph by Y. Kholopov and V. Tsenova is also taking specialized scientific attention from authors of this represented investigative work. The disquisition, which is dedicated to E. Denisov's creativeness, supports on the wide factual material, what essentially clarifies the completive list of composer's creative works. There is vocational looking to the Solo for trumpet by E. Denisov on the pages of the above-indicated collective monograph, what is supplementing the above-mentioned D. Shulgin's monograph exploration.

Unfortunately, the musically pedagogical aspect of the wind solo compositions by E. Denisov continues to be without the particularized attention from the side of many pedagogues-scientists, which represent the sphere of contemporary academic musical pedagogy.

The purpose of this submitted scientific material is revealing the musically pedagogic peculiarity, the series of brightly expressive factors, criterions concerning the compositions for wind instruments solo (wood and brass academic instruments) by E. Denisov.

Specific attention of teacher for classes of wind professional instruments to the masterpieces solo by E. Denisov is stipulated, in the first place, by artistically holistic looking by renowned composer of expressive means regarding one or another wind instrument, by mastery of flexibly and expressively to connect the traditional and innovative means of musical expression, which are applying into the modern music for academic wind instruments. Herewith, E. Denisov, possessing the enormous pedagogical experience of practice lessons with students into the course "Instrumentation" at the Moscow State Conservatory after name P.I. Tchaikovsky, essentially changes the traditional looking of expressive means concerning wind instruments into the compositions solo.

\footnotetext{
Вискова И. В. Пути расширения выразительных возможностей деревянных духовых инструментов в музыке второй половины XX в. : автореф. дис. ... канд. искусствоведения: 17.00.02. Москва, 2009. 25 с.

${ }^{4}$ Крупей М. Теоретичні основи формування виконавської майстерності саксофоніста. Одеса : Астропринт, 2014. 496 с.

Данилова А. Своеобразие интерпретации категории «традиция» в эстетической теории и практике постмодернизма (на материале творчества Э. Денисова) : автореф. дис. ... канд. философских наук: 09.00.04. Москва, 2009. 24 с.

${ }^{6}$ Громченко В. К вопросу диалогичности жанра музыки для инструмента соло (на примере сонаты для кларнета соло Э. Денисова). Художественное произведение в современной культуре: творчество - исполнительство - гуманитарное знание. 2014. С. 81-90.
} 
Underline, that the new artistic reading by composer of bassoon's high register is the center of teacher's pedagogical attention in reference to the E. Denisov's Sonata for bassoon solo. Timbre-coloristic as well as timbredynamic possibilities of contemporary bassoon into the high, extreme sounds of bassoon's range, were essentially weakened by the instrument's nature, in particular, a strength of bassoon's sounding in the high register is minimal. Nevertheless, the composer has carried the intonation-expressive accent to the melody, cantilena nature of professional bassoon, what have made the amazingly specific expression of bassoon's melodic utterance, specialized pronunciation namely, emphasize, into the extremely high sounds of bassoon's range.

There is the characteristic saying of E. Denisov in relation to abovementioned thinking. "The bassoon's scherzo opportunities is exhausted by musicians and this is absolutely understanding for all creators, as saying, it lays on the surface. Nevertheless, expressive possibilities of bassoon are already not exhausted by masters. Bassoon is enormously expressive instrument and amazingly interesting in reference to its sounding. The modern bassoon specifically unusually sounds into the high register. There is absolutely unrivaled artistic timbre to here, but sometimes, approaching to the saxophone's timbre. For me, on the example, it was interesting to write almost all second part only at the soprano key, in the essence, at the remarkably high bassoon's register" ${ }^{\text {"7 }}$.

In this connection, the important problem, pedagogical task namely to accent the attention of young musician-performer on the intonation hearing imaginations, on the sensation by student of particularity concerning melodic instrumental intonation, which is fundamental basis of individual professional solo performing process is generated by E. Denisov's compositions solo for present-day academic pedagogue. "It's known, that development of intonation control is essential, significant part of contemporary training-educational process regarding professional instrumental music"

Note, that the maximal attention to the virtuously technical possibilities of playing on wind brass academic instrument is main, key task for pedagogical work with young musician in relation to brilliant instrumental miniature Solo for trumpet by E. Denisov. Artistic performing on the brass wind instruments, as a rule, was not marked by diversity of performing virtuous technique namely small, large, combinative types. Fanfare-solemn as well as melodic hypostasis of "image" for this instrument are traditional defining the artistic characterization of academic trumpet, what is doing finger-activity, virtuously-technical side concerning performing process the less requested. But, the contemporary trumpet is disclosed by composer in the maximally virtuous aspect, with the requirement about working the all performing

\footnotetext{
${ }^{7}$ Шульгин Д. Признание Эдисона Денисова. Москва : Композитор, 1998. С. 297-298.

${ }^{8}$ Latten J. Exploration of a sequence for teaching intonation skills and concepts to wind instrumentalists. Journal of band research. 2005. Vol. 41. Is. 1. P. 60.
} 
apparatus of modern musician. E. Denisov artistically-exquisitely involves the small virtuous technique, which dominates in the performing of this academic wind composition solo.

Thereby, we can say about the essential renovation of pallet regarding traditional artistically expressive means, which are applying in the new masterpieces for present-day trumpet. Consequently, E. Denisov significantly expands the limits of the traditional musical utterance in reference to wind professional instrumentation, into the process of incarnation the contemporary artistically-imaginative ideas for these academic instruments. It is the understanding of these modern possibilities for wind instruments, working with concrete performing methods, by means of which the opening of these opportunities, are producing the new "image" of academic wind instruments. Highlight, that this is particularized core for the pedagogical process into the classes of wind professional instruments at the high musical training educational institutions.

The pedagogues' specialized attention into the classes of wind academic instruments, during the working with E. Denisov's compositions solo, is taken by teachers and students to the mastery of the most contemporary nontraditional artistically expressive means, which are usually using in the wind masterpieces solo by called composer. One of the characteristic compositions, into this significance, meaning, is Sonata for clarinet solo by E. Denisov. It is essential part of the current pedagogical, concert, competitive, festival as well as concert-educational repertoires for many present-day clarinetists. Celebrated composer has spoken the next in relation to this masterpiece solo. "I have not seen a single clarinet player, who would not play this Sonata".

We can underline the series of technological modern artistically expressive means. The wind performing methods as the oscillations, portamento and presentation of musical material in the technique of microintervalics (microchromatics) testify about the innovation of this wind composition solo from the point of view concerning modern performing techniques of contemporary performer-clarinetist.

The above-mentioned is generating the process of writing the corresponding explanatory spreadsheets concerning the non-traditional artistic-expressive means at the sphere of modern professional musical culture. These tables are important part of the musically-pedagogical process in the contemporary musical educational institution. "The tendency to the complexity of musical pronunciation, intonation language is put on the increasing status of composer explanations" $"$.

The author of modern musical composition, as a rule, gives the specialized explanations for those or other non-traditional means of artistic expression,

\footnotetext{
${ }^{9}$ Шульгин Д. Признание Эдисона Денисова. Москва : Композитор, 1998. С. 222.

${ }_{10}$ Рондарев А. Страх повторения. Философские, метафизические и методологические воззрения Владимира Мартынова. Логос. 2016. Т. 26. № 4. С. 121.
} 
which are used by composer in the certain masterpiece. This kind of clarifications are very often represented by modern-day musical authors in the form of determined spreadsheets, on the example, the fingering particularity for performing of multiphonics, microintervalics (microchromatics), movements of musician during performing of professional academic composition solo and etcetera.

The appeal of E. Denisov to the non-traditional contemporary means of musical expression is also discovered into the wind compositions solo namely "Pastoral" and "Movement" for flute solo. It is here, the main starting point for writing these stage-individual masterpieces grows out from the technique of multiphonics, different innovative instrumentally-performing methods, timbre coloristic features in relation to the peculiar sounding of wind academic instrument and etcetera. "These pieces were written by request of very fine publishing house in Leipzig - "Deutscher Verlag für Music". This publishing center had printed the enormous series of pedagogical compilations, intended for divers' professional instruments. The overall purpose of these kind collections is the attraction of contemporary composers for the special academic writing of artistically bright pieces for instruments solo as well as applying into these masterpieces as much as possible new, present-day instrumentally technical methods concerning the process of playing on these academic instruments" $" 11$.

Above-indicated is testifying that the task of understanding by modern musician-performer the definite aspects of musical art's communicative function is actualized by present-day creators at the domain of vocational performing on the wind instruments solo. First of all, this is inner dialog, conversation of instrumentalist with oneself in the process of mastery and reproduction of contemporary artistically expressive means; this is overcoming of certain psychological limits into noted process. There is inner dialog of performer-soloist with composer during the comprehension of author's conception, which was materialized by creator at the text musical composition. Finally, the main task for any musical performer concentrates the process of carrying to audience of artistic plan, artistically expressive idea regarding one or another masterpiece. This mission is complicated by musical performing of wind pieces, which are noted by non-traditional images, emphasize, the contemporary means of artistic expression. In the same time, the performer-soloist always feels concert hall, listeners and their creative reaction. Consequently, this is specialized academic dialog with recipient: " $<\ldots>$ any text, and monologue too, must be considered by performer as the double-sided $<\ldots>$..

\footnotetext{
${ }^{11}$ Шульгин Д. Признание Эдисона Денисова. Москва : Композитор, 1998. С. 305.

${ }^{12}$ Скорик К. Диалогизация художественного текста: типы и способы её актуализации в англоязычной прозе : автореф. дис. ... канд. филол. наук: 10.02.04. Санкт-Петербург, 2010. С. 8. 
Not by chance, the tasks, connected with incarnation of all abovementioned aspects concerning communicative function of solo performing process, are some of the most complex, difficult as well as topicality into the modern-day pedagogical process at development, in mastering by innovative musical compositions, masterpieces of celebrated musicians E. Denisov. The present-day teacher, which involves at the pedagogical work the opuses by above-indicated composer, essentially actives the understanding by student of communicative, dialogical essence of musically performing art. Vocation pedagogue reveals the amazingly bright phenomenon of academic musical dialog not only in its outside comprehension, but into its inside artistic aspects.

We are emphasizing that it is the creative act of one musician-soloist into the most extant actives the phenomenon of dialogicality in reference to musically intonation pronunciation. Collective and ensemble-orchestral performing requires the particularized ensemble technological perfection and levels, principally grades the wide spectrum of above-mentioned dialogicality between academic musician-soloist and audience of listeners.

Important musically pedagogical factor concerning discovering of wind performing solo at the practice of modern musical culture touches the evolution of artistically imaginative thinking of nowadays learners. Aforementioned the modernization of traditional expressive means, applying contemporary expressive colors, accentuating of divers types, kinds of dialogicality at the single-stage creative act of musician-soloist fundamentally actives the imaginative thinking of present student. Underline those musically instrumental compositions of academic wind solo by E. Denisov are not own the specialized characteristic artistic program. Consequently, the process of disclosing of characterization of academic wind masterpieces solo is connected by professional pedagogue, directly, with active artistically imaginative thinking of learner. In this connection, outstanding composer accents the next judgments (this is about famous Sonata for clarinet solo): " $<\ldots>$ if a person-musician has not guessed the particularized artistic character, that is, everything that is all together in the composition, then the whole musical masterpiece "falls", 13

Underscore those specific tasks in reference to wind compositions solo by E.V. Denisov is connected by vocational teachers with absolute absence of the precise time limits for performing of E. Denisov's masterpieces solo. It is this produces, generates for professional musician-soloist the phenomenon of creative freedom. This makes the new pedagogical task namely the upbringing of performing culture, very good artistically taste for young academic pupil, student. Give the example with the wide outstanding composition for oboe solo by L. Berio. "The famous score of Luciano Berio's

\footnotetext{
${ }^{13}$ Шульгин Д. Признание Эдисона Денисова. Москва : Композитор, 1998. С. 222.
} 
"Sequenza VII" for solo oboe exhibits a strict and definite temporal space, yet most vocational performers do not manage to perform the work within the prescribed time" 14 . Give the next example concerning this subject namely masterpiece "Harlequin" for clarinet solo by celebrated composer $\mathrm{K}$. Stockhausen, where there is " $<\ldots>$ vectors of imaginative as well as melodic transformations"

The renowned investigator of the academic etude genre I. Nosova says the next that " $<\ldots>$ a musical traditional etude, primarily as the exercise and motor movement, which did not have unchanging genre, in the work of composers-teachers such as K. Cherni, S. Moshkovsky and others, bright formed into a certain completed structure. Later, he has got the opportunity to display certain emotions as well as feelings, and became a full-fledged work of art" ${ }^{\prime 6}$. The bassoon's etudes by E. Denisov are just such musically wonderful professionally academic wind works solo.

In consequence, the central pedagogical problems that stand up when learners master brilliant compositions for wind instruments solo by E. Denisov are connected by investigators with the following locations: a) regeneration of traditional expressive means, ideas concerning the possibilities of professional academic wind instruments; b) the applying by composer the non-traditional means of instrumental artistic expression (for example the composer techniques, the innovative performing techniques as well as effects and etcetera; c) actualization the primarily understanding by teacher and next a pupil, student the problem for the student's awareness of the communicative essence of musical performance (namely external, internal dialogicity); d) activation of the student's artistically imaginative sophisticated thinking, underscore, in the process of comprehending the artistic, ideally expressive content of the brilliant academic masterpieces, wrote for wind professional instruments solo by E. Denisov.

Unquestionably, the above-mentioned represents a relief-defined musical as well as bright pedagogical specificity, educational and characteristic originality; certain pedagogical factors are produced, generated by masterpieces for professional academic wind instruments solo by E. Denisov.

\section{The compositions of wind solo by E. Denisov}

\section{in the context of distance musically-pedagogical communication}

The masterpieces of wind solo by E. Denisov possess the specific musically pedagogical significance into the light of contemporary sanitaryepidemiological situation, which has shown in many countries of the world.

\footnotetext{
${ }^{14}$ Barrier O., Panebianco C. Towards a precise calculation of the total intended duration of Luciano Berio's Sequenza VII for solo oboe. Muziki-journal of music research in Africa. 2019. Vol. 16. Is. 1. P. 61.

15 Галлямова Г. «Арлекин» К. Штокхаузена: на пересечении идей формульной композиции и инструментального театра. Вестник Томского государственного университета. 2013. Вып. 369. С. 57.

${ }^{16}$ Носова И. К проблеме влияния социокультурных аспектов на эволюцию музыкального жанра (на примере этюда). Вестник Томского государственного университета. 2007. Вып. 303. С. 47.
} 
The modern forms of training-educational process into academic musical pedagogy are impetuously activated by the hard quarantine measures of struggle with the pandemic of coronavirus COVID-19. In the first place, we understand for those specialized measures, certain methods the distance acts of professional pedagogical communication between professor and student.

Emphasize, that distance form of professional musical learning, with full applying maximal multiplicity of contemporary innovational technologically progressive communicational instrumentation, particularized equipment (Skype, Viber, Telegram, WhatsApp, Facebook Messenger), is absolutely single possibility for system, educationally-plan academic training with modern-day students, disciples in the present day.

Underline, that educational subject "Special instrumental class" is one of the main into time as well as professionally educative equivalent of learning with pedagogues, in the light academically specialized subjects at the high musical educational institutions. The crucial significance of this subject is stipulated by not only fact of technical mastery of professional academic instrument (wood and brass wind instruments), but also by important criterions concerning artistic upbringing of student, by the process of forming in him different individual qualities in reference to musician-artist.

The subject "Special instrumental class", in relation to students for specialization "Orchestral wind academic instruments", traditionally defines the ensemble, collaborative contact musician-soloist with pianist-accompanist, with direct participant concerning training-instructive process at the professional educational institution. This kind vocational communication with accompanist is not physically able into the complicated period of the hard quarantine and self-isolation. Consequently, there is actualization of the question about different forms regarding educational process, in which the absence pianoforte accompaniment for instrumentalist-soloist will not give a degradation relatively the development of a student's artistic upbringing. It is in this context reveals the amazingly particular significance, connotation of wind solo compositions (without any accompaniment), which variously represented in the creativeness by celebrated composer E. Denisov. In this connection, distance form learning postulates the contemporary complex of questions and actual peculiarities of modern pedagogical process, which is constructed by impetuous mastering, familiarization by students the multiplicity academic masterpieces of wind solo.

The mobility in relation to professional communication of teacher with student is relief disclosed into the form distance training-educational process with applying of wind solo compositions. Learner has brilliant possibility to a rush connection with pedagogue as well as confident opportunity to a correlation, detail clarification, emphasize, all parts of a process in reference to studying one or another wind solo masterpiece. 
Herewith, vocational communion of teacher with pupil can have the characterization of a step-by-step relatively training-educational communication. Student records some playing variants of artistic composition solo and sends the best variant to the pedagogue whereby the contemporary electronic connection. Professor analyses the received student's recording and scrutinizes, specifies the all positive as well as negative sides of pupil's playing, underline, into the direct, online-communion with disciple. Further, young musician, making a lot of specialized recordings for future performing analysis, creates many quantity of performing tries, instrumental attempts for next choosing of the best playing variant, what, into the end result, generates definite selfactualization of distance professional training-instructional process.

It is important to emphasize, that wind solo compositions are very often applied by creative personalities in online auditions within the framework of many competitively creative contest, competitive auditions with the purpose in relation to receiving the certain work place into the specific ensemble, orchestral collectivities as well as into the process for determining of qualification and work place at the sphere of professionally pedagogical activity.

Significant role of academic masterpieces for many wind professional instruments solo by E. Denisov into the context above-mentioned features of distance education is revealed in musically artistic upbringing of contemporary students. These compositions solo by represented composer are amazingly complicated, very sophisticated into the technically performing, virtuously technological aspects. There are almost all particularized kinds of wind performing technique namely virtuously fingers, articulation and touching technique, technique of performing breathing, attenuation of instrumental sound and etcetera. It is this criterion essentially activates of the motivational part in reference to modern distance training educational process.

The creative freedom as a psychophysiological factor, which is specifically expressively disclosed by musician into the performing of wind solo masterpieces by renowned E. Denisov, contributes to the making of artistically expressive, performing confident, originally interpretational versions concerning above-indicated academic compositions solo by represented composer.

E. Denisov, which investigated structural foundations of compositional process, deepened into the secret of birth regarding artistic composition, has written the next: "The present musical masterpiece is not artistic simple. Than further we penetrate into its secrets, the more delight we experience. But always, there is one door, which was closed, how much time we had returned to this musical work and how deeply our analytical look had penetrated into this composition. It is in this inexhaustibility there is specific strong and particular attraction, magnetism of all truly great into the art" ${ }^{\prime 17}$.

${ }^{17}$ Денисов Э. О композиционном процессе. Эстетические очерки. 1979. Вып. 5. С. 136. 
Nevertheless, the criterion of artistic, creative freedom, which is specifically bright sensed by musician into process of performing wind solo compositions by E. Denisov, contributes to increasing of level concerning individual organization of student, what, undoubtedly, approves the constant dynamic of quality for pedagogical process into the form of distance communication between contemporary teacher and pupil. In it is turn, the multiplicity of interpretational versions relatively wind solo masterpieces by E. Denisov activates creative independence, imaginative thinking of student as well as stimulates the independence regarding artistically creative solutions of pupil in reference to one or another wind solo academic composition. Accentuate, that it is in this context there is enlargement, magnification of artistically performing activity in relation to, without exception, the all pallet of artistically expressive means (timbre, dynamic, touches, articulation, attack of instrumental sound, phrasing, agogic, melismatics, fingering, performing as well as non-traditional artistically expressive means and etcetera).

\section{CONCLUSIONS}

Thereby, the main pedagogical problems, which are connected with familiarization by young musicians the E. Denisov's compositions for wind instruments solo, are directed to the performing thinking of modernization concerning traditional artistically expressive means of the academic wind professional instrumentation, to the evolution of traditional and contemporary artistic means (the performing methods, effects and etcetera), to the process of understanding the communicational essence of academic musical art (outside and inside dialogism) as well as, what is primarily important for upbringing of modern professional musician, to the activation of student's artistically imaginative thinking. The above-mentioned allow us to approve, that, into the light of all negative sides relatively distance form learning in the sphere of wind academic musically performing art (the complexity regarding relationship of pedagogue with student in reference to performing technological questions, the absence non-verbal methods in the trainingeducational process, week organization of disciplinary-time schedule, the absence of emotional contact for professor with student and etcetera), compositions for wind instruments solo by E. Denisov are noted by amazingly sophisticated complex and multiplicity of imaginative pallet, the enlargement of artistically expressive means, contribution to the supporting by student the certain professionally performing form as well as activation of independent pupil's work into the conditions concerning the absence of direct system training-instructional contact with pedagogue of academic wind professional musically performing art. 


\section{SUMMARY}

The purpose of represented scientific material is revealing of musically pedagogical particularity, the series of key and amazingly crucial as well as the most significant training-educational criterions of compositions for wind instruments solo by E. Denisov. In this time period, the contemporary pedagogical repertoire for upbringing of modern professional performer one or another wind academic instrument have not already absolutely contact with pianist-accompanist, with sounding of part's fortepiano-accompaniment. The impetuous magnification of quantity concerning stage-individual masterpieces solo for wind professional instruments, which is appeared from the second half of the $20^{\text {th }}$ century in the most extent, have marked by enormously progressive dynamic into this time of postmodernism epoch. It is this generates the reality of lessons with contemporary students without pianistaccompanist, because many modern wind compositions were initially written by composers for only one academic professional instrument. E. Denisov is unsurpassed master in the academic musically performing form solo concerning the coverage of wind professional instrumentations as well as genre pallet for artistic representation of wind solo compositions. Such wind masterpieces as Solo for flute (1971), Solo for oboe (1971), Sonata for clarinet solo (1972), Solo for trumpet (1972), Sonata for bassoon solo (1982), Sonata for flute solo (1982), Two pieces "Pastoral" and "Moving" for flute solo (1983), Five etudes for bassoon solo (1983) are specialized material for this represented scientific investigation. Peculiar pedagogical attention from a pedagogue of classes' wind instruments to the compositions solo by E. Denisov is stipulated by, in the first place, artistically holistic observation by famous composer of expressive means in relation to one or another wind professional instrument. Master enormously flexibly connects the traditional and contemporary means of artistic expression relatively academic wind instrumentation. There are fundamental indications of musically pedagogical particularity concerning compositions for wind instruments solo by celebrated E. Denisov, among which we will note, first of all, essential renovation of understanding about possibilities regarding wind professional instrumentation (wood and brass academic instruments), evolution for means of artistic expression (performing methods, effects, non-traditional artistically expressive means and etcetera), accentuation of awareness touching communicational essence of academic musical art (outside and inside dialogism), significant activation of student's artistically imaginative thinking, important realization of multifaceted and versatile opportunities in reference to professional musically educational process in the modern distance training-instructional communication between contemporary student and pedagogue. 


\section{REFERENCES}

1. Апатский B. История духового музыкально-исполнительского искусства. Киев : Задруга, 2012. 408 с.

2. Буркацький 3. Особистісно орієнтований підхід до віртуозності кларнетиста. Одеса : Друкарський дім, 2010. 166 с.

3. Вискова И. Пути расширения выразительных возможностей деревянных духовых инструментов в музыке второй половины XX в. : автореф. дис. ... канд. искусствовед.: 17.00.02. Москва, 2009. 25 с.

4. Крупей М. Теоретичні основи формування виконавської майстерності саксофоніста. Одеса : Астропринт, 2014. 496 с.

5. Данилова А. Своеобразие интерпретации категории «традиция» в эстетической теории и практике постмодернизма (на материале творчества Э. Денисова) : автореф. дис. ... канд. филос. наук: 09.00.04. Москва, 2009. 24 с.

6. Громченко В. К вопросу диалогичности жанра музыки для инструмента соло (на примере сонаты для кларнета соло Э. Денисова). Художественное произведение в современной культуре: творчество исполнительство - гуманитарное знание. 2014. С. 81-90.

7. Шульгин Д. Признание Эдисона Денисова. Москва : Композитор, 1998. $464 \mathrm{c}$.

8. Kholopov Y., Tsenova V. Edison Denisov. Chur, Switzerland : Harwood Academic Publishers, 1995. 244 p.

9. Latten J. Exploration of a sequence for teaching intonation skills and concepts to wind instrumentalists. Journal of band research. 2005. Vol. 41. Is. 1. P. 60-87.

10. Рондарев А. Страх повторения. Философские, метафизические и методологические воззрения Владимира Мартынова. Логос. 2016. Т. 26. № 4. С. 119-149.

11. Скорик К. Диалогизация художественного текста: типы и способы её актуализации в англоязычной прозе : автореф. дис. ... канд. филологических наук: 10.02.04. Санкт-Петербург, 2010. 20 с.

12. Barrier O., Panebianco C. Towards a precise calculation of the total intended duration of Luciano Berio's Sequenza VII for solo oboe. Muzikijournal of music research in Africa. 2019. Vol. 16. Is. 1. P. 61-73.

13. Галлямова Г. «Арлекин» К. Штокхаузена: на пересечении идей формульной композиции и инструментального театра. Вестник Томского государственного университета. 2013. Вып. 369. С. 57-59.

14. Носова И. К проблеме влияния социокультурных аспектов на эволюцию музыкального жанра (на примере этюда). Вестник Томского государственного университета. 2007. Вып. 303. С. 45-48.

15. Денисов Э. О композиционном процессе. Эстетические очерки. 1979. Вып. 5. С. 126-136. 


\section{Information about authors:}

Nemkovich O. M.,

Doctor of Arts,

Head of the Department of Screening-Stage Arts and Cultural Science Rylsky Institute of Art Studies, Folklore and Ethnology of the National Academy of Sciences Ukraine

4, Hrushevsky str., Kyiv, 01001, Ukraine Hromchenko V. V.,

Candidate of Arts, Associate Professor,

Vice Rector of Research Work

Mikhail Glinka Dnipropetrovsk Academy of Music

10, Liteinay str., Dnipro, 49044, Ukraine 